\title{
De hervorming van het bewijsrecht in België
}

\author{
Een spiegeling aan het huidige en toekomstige Nederlandse recht
}

\author{
Wannes Vandenbusscbe*
}

\begin{abstract}
1 Inleiding
Sinds een aantal jaren is er een opvallende hervormingsbeweging aan de gang in het Belgische recht. Een van de belangrijkste uitingen hiervan is de invoering van een nieuw Burgerlijk Wetboek bij wet van 13 april 2019. ${ }^{1}$ Zoals vaker het geval is, volgde de Belgische wetgever het voorbeeld van Frankrijk. De Franse wetgever hervormde reeds in 2016 op grondige wijze het contractenrecht, het algemeen regime van de verbintenis en het bewijsrecht. ${ }^{2}$ Anders dan de Franse wetgever, die de gewijzigde bepalingen heeft ingevoegd in de Code civil van 1804, opteerde de Belgische wetgever voor een volledig nieuw Burgerlijk Wetboek. Dit wetboek zal op termijn uit negen boekdelen bestaan, ${ }^{3}$ waarvan er op dit moment twee zijn ingevuld: Boek 3 'Goederen' en Boek 8 'Bewijs'. Terwijl de hervorming van het goederenrecht reeds de nodige aandacht heeft gekregen in Nederland, ${ }^{4}$ is de hervorming van het bewijsrecht grotendeels onopgemerkt voorbijgegaan. ${ }^{5}$ Nochtans vormt Boek 8 'Bewijs' de eerste bouwsteen van het nieuwe Burgerlijk Wetboek. Deze bijdrage heeft als doelstelling om een aantal hoofdlijnen van het hervormde Belgische bewijsrecht in de
\end{abstract}

* Prof. dr. W. Vandenbussche is docent Burgerlijk Procesrecht aan het Instituut voor Procesrecht van de UGent en advocaat bij de Balie van Brussel.

De auteur wenst de anonieme peerreviewers en de TCR-redactie te bedanken voor hun nuttige commentaren bij een eerdere versie van deze bijdrage.

1 Wet van 13 april 2019 tot invoering van een Burgerlijk Wetboek en tot invoeging van boek 8 'Bewijs' in dat Wetboek, BS 14 mei 2019, p. 46.353.

2 Ordonnance $n^{\circ}$ 2016-131 du 10 février 2016 portant réforme du droit des contrats, du régime général et de la preuve des obligations.

3 Boek 1. Algemene bepalingen; Boek 2. Personen, familie en relatievermogensrecht; Boek 3. Goederen; Boek 4. Nalatenschappen, schenkingen en testamenten; Boek 5. Verbintenissen; Boek 6. Bijzondere overeenkomsten; Boek 7. Zekerheden; Boek 8. Bewijs; Boek 9. Verjaring.

4 Zie het themanummer van NTBR (afl. 7 van 2021), waarin verschillende auteurs reflecteren op een aantal in het oog springende onderdelen van het vernieuwde Belgische goederenrecht.

5 Met uitzondering van een kort overzicht van de genese en de belangrijkste beginselen door prof. dr. B. Vanlerberghe (zie B. Vanlerberghe, 'Het nieuwe Belgische burgerlijke bewijsrecht', WPNR 2021, afl. 7338, p. 650-658) en het opstel van emeritus hoogleraar D. Asser (zie W.D.H. Asser, 'België en Nederland en een nieuw burgerlijk bewijsrecht. Enkele Hollandse observaties', in: J. Altena e.a. (red.), In onderlinge samenhang. Liber amicorum Tineke Cleiren, Den Haag: Boom juridisch 2021, p. 145154). verf te zetten en deze hervorming te spiegelen aan het Nederlandse recht.

Daarbij zal het de Nederlandse lezer opvallen dat het nieuwe bewijsrecht nog steeds bijzonder trouw is gebleven aan de napoleontische traditie. Doorheen de bijdrage zal blijken dat de Belgische hervorming op bepaalde punten zelfs behoudsgezinder is dan de regeling van het bewijsrecht in burgerlijke zaken die de Nederlandse wetgever in 1988 heeft ingevoerd (zoals met betrekking tot het gereglementeerde bewijsstelsel). Daarnaast houdt het Belgische recht, net zoals het Franse recht na de hervorming van 2016, vast aan de tweedeling tussen de (materiële) regels inzake bewijslast, de bewijsmiddelen en de toelaatbaarheid in het Burgerlijk Wetboek en de (formele) regels inzake de bewijsvoering en de onderzoeksmaatregelen in het Gerechtelijk Wetboek. Het Nederlandse recht ontdeed zich daarentegen reeds drie decennia geleden van de opsplitsing tussen het materiële bewijsrecht in het oud Burgerlijk Wetboek en het formele bewijsrecht in het Wetboek van Burgerlijke Rechtsvordering. Men beschouwde dit immers als een 'in scherpte tekortschietend en niet consequent doorgevoerd onderscheid'. ${ }^{6}$ Het inzicht dat het burgerlijke bewijsrecht als geheel beter op zijn plaats is in het Wetboek van Burgerlijke Rechtsvordering heeft toen de bovenhand gehaald. ${ }^{7}$ Deze kwestie is in de Belgische hervorming zelfs niet aan de orde gekomen. ${ }^{8}$ Dat is te betreuren, maar de opdracht van de ministeriële commissie ter hervorming van het bewijsrecht was nu eenmaal beperkt tot de hervorming van de bewijsregels in het Burgerlijk Wetboek.

Het voorgaande heeft bovendien tot gevolg dat er weinig gelijkenissen bestaan tussen de recente Belgische hervorming en het Nederlandse wetsvoorstel vereenvoudiging en moderni-

6 G.R. Rutgers \& R.J.C. Flach, Parlementaire geschiedenis van de nieuwe regeling van het bewijsrecht in burgerlijke zaken, Deventer: Kluwer 1988, p. 9.

7 H.L.G. Dijksterhuis-Wieten, Bewijsrecht in civiele procedures, Deventer: Kluwer 1998, p. 1.

8 Hoewel er lezenswaardige reflecties bestaan over de rol van de bewijsregels binnen het materiële recht versus procesrecht; zie M.E. Storme, 'De goede trouw in het geding? De invloed van de goede trouw in het privaat proces- en bewijsrecht', TPR 1991, p. 488-489, nrs. 94-95. 
sering bewijsrecht (hierna: Wetsvoorstel 35498). ${ }^{9}$ De belangrijkste hervorming van het Nederlandse bewijsrecht vond al plaats in 1988. Het Nederlandse Wetsvoorstel 35498 bouwt daarop voort. De nieuwe Belgische regeling moet dus in de eerste plaats worden vergeleken met de Nederlandse hervorming van 1988. Niettemin zal ik hierna toelichten dat er op één punt, namelijk de verplichting van partijen tot medewerking aan de bewijsvoering (art. 8.4, derde lid BW), ook enige overlap is tussen het hervormde Belgische bewijsrecht en de wijzigingen die het Wetsvoorstel 35498 vooropstelt.

Hierna sta ik eerst even stil bij het ruimere kader waarbinnen de hervorming van het Belgische bewijsrecht te situeren is (zie par. 2). Aansluitend schets ik vier hoofdlijnen die de hervorming kenmerken. Deze heb ik gedestilleerd uit de wettekst en de memorie van toelichting (zie par. 3). De doelstelling is niet om een allesomvattend overzicht te geven van het volledige hervormingsproject. Dat is niet mogelijk binnen het bestek van deze bijdrage. Bovendien is de relevantie van een gedetailleerde analyse van de Belgische regelgeving voor de Nederlandse lezer beperkt. Indien de lezer daar toch interesse in zou hebben, verwijs ik graag naar de talrijke bijdragen die in de afgelopen periode in België verschenen zijn. ${ }^{10}$ Afsluiten doe ik met een aantal korte slotbeschouwingen (zie par. 4).

\section{Totstandkoming}

Het startschot voor de hervorming van het bewijsrecht werd gegeven in 2015. Toen kondigde de algemene beleidsnota Justitie een grondige hervorming aan van het Burgerlijk Wetboek, omdat belangrijke delen 'verouderd en onoverzichtelijk' waren geworden. ${ }^{11}$ Het bewijsrecht was één van zes domeinen

9 Voorstel van Wet tot wijziging van het Wetboek van Burgerlijke Rechtsvordering en enige andere wetten in verband met de vereenvoudiging en modernisering van het bewijsrecht, Kamerstukken II 2019/20, 35498 , nr. 2

10 Zie o.m. B. Allemeersch \& A.-S. Houtmeyers, 'Kennismaking met het nieuwe bewijsrecht', TBH 2019, p. 624-641; J. Baeck, 'Boek 8 "Bewijs": het eerste boek van het nieuw Burgerlijk Wetboek', $R W$ 2019-20, afl. 29, p. 1121-1143; N. Clijmans, 'Het nieuwe bewijsrecht in burgerlijke en ondernemingszaken. Een kennismaking middels artikelsgewijze commentaar', in: M-C. Van den Bossche, C. De Backere \& Vlaams Pleitgenootschap bij de Balie van Brussel (red.), Proces-en bewijsrecht: capita selecta, Mechelen: Kluwer 2019, p. 83-108; F. George, 'Le nouveau droit de la preuve. Quand le huitième wagon devient locomotive!', JT 2019, p. $637-$ 657; D. Mougenot, B. Allemeersch \& W. Vandenbussche, De hervorming van het bewijsrecht/La réforme du droit de la preuve, Brugge: die Keure 2019; D. Mougenot (red.), La réforme du droit de la preuve, Luik: Anthemis 2019; J. Rozie, S. Rutten \& B. Vanlerberghe (red.), Bewijsnood na het vernieuwde bewijsrecht, Antwerpen: Intersentia 2020; I. Samoy \& W. Vandenbussche, 'Het nieuw bewijsrecht', in: S. Stijns (red.), Themis Verbintenissenrecht, Brugge: die Keure 2019, p. 117-153; W. Vandenbussche \& N. De Lathauwer, 'Het hervormde bewijsrecht. Capita selecta', in: S. Voet \& B. Allemeersch (red.), Themis Gerechtelijk Recht, Brugge: die Keure 2020, p. 71-95; B. Vanlerberghe, Het nieuwe burgerlijke bewijsrecht, Antwerpen: Intersentia 2019; T. Vansweevelt \& B. Weyts (red.), Het nieuwe bewijsrecht, Antwerpen: Intersentia 2020.

11 Algemene beleidsnota Justitie, Parl. St. Kamer 2015-16, nr. 1428/008, 44. waarvoor een werkgroep werd opgericht. ${ }^{12}$ Iedere werkgroep had als opdracht om wijzigingen voor te bereiden met als doel om het wetboek modern en transparant te maken.

De ministeriële commissie ter hervorming van het bewijsrecht rondde haar voorbereidende werkzaamheden af in het najaar van 2017. Het resultaat daarvan vormde de basis voor een voorontwerp van wet. $\mathrm{Na}$ een gunstig advies van de Raad van State op 27 juni $2018^{13}$ en een goedkeuring in tweede lezing door de ministerraad op 25 oktober 2018, werd het Boek 8 'Bewijs' als Wetsontwerp van 31 oktober 2018 ingediend bij de Kamer van Volksvertegenwoordigers. ${ }^{14}$ Op 4 april 2019 keurde de plenaire vergadering het Wetsontwerp van Boek 8 'Bewijs' goed als eerste onderdeel van het hervormingsproject. Op 14 mei 2019 werd de wet van 13 april 2019 tot invoering van een Burgerlijk Wetboek en tot invoeging van boek 8 'Bewijs' in dat Wetboek gepubliceerd in het Belgisch Staatsblad. ${ }^{15}$ Deze wet is op 1 november 2020 in werking getreden. ${ }^{16}$ Sinds de inwerkingtreding van die wet draagt het Burgerlijk Wetboek van 1804 het opschrift 'oud Burgerlijk Wetboek' (hierna: oud BW). ${ }^{17}$ Het nieuw Burgerlijk Wetboek wordt sindsdien aangeduid als het 'Burgerlijk Wetboek' (hierna: BW).

\section{De vier hoofdlijnen}

Boek 8 'Bewijs' bestaat uit drie hoofdstukken: een eerste hoofdstuk met algemene bepalingen, een tweede hoofdstuk over de toelaatbaarheid van de bewijsmiddelen en een derde hoofdstuk over de bewijsmiddelen zelf. Weinig verrassend vermeldt de eerste zin van de parlementaire voorbereiding dat Boek 8 als doelstelling heeft om het bewijsrecht te moderniseren. ${ }^{18}$ Uit de memorie van toelichting en de wettekst kunnen vier hoofdlijnen worden gedestilleerd: het toegankelijk maken en codificeren van het geldende recht (zie par. 3.1), het bevestigen van het gereglementeerde bewijsstelsel, maar met een versoepeling van het bewijsformalisme (zie par. 3.2), het aanpassen van het bewijsrecht aan de moderne samenleving (zie par. 3.3) en het verduidelijken van de regels inzake de bewijslast en de bewijsstandaard (zie par. 3.4).

12 Naast het verbintenissenrecht, goederenrecht, aansprakelijkheidsrecht, lening en persoonlijke zekerheden (zie MB 30 september 2017 houdende oprichting van de Commissie tot hervorming van het Burgerlijk Wetboek, $B S 9$ oktober 2017, p. 91.600).

13 Adv.RvS nr. 63.445/2 van 27 juni 2018.

14 Wetsontwerp van 31 oktober 2018 houdende invoeging van Boek 8 'Bewijs' in het nieuw Burgerlijk Wetboek, Parl. St. 2018-19, nr. 3349/001, p. 1-130.

15 Wet van 13 april 2019 tot invoering van een Burgerlijk Wetboek en tot invoeging van boek 8 'Bewijs' in dat Wetboek, BS 14 mei 2019, p. 46.353 (hierna: Wet 13 april 2019).

16 Art. 75, eerste lid Wet 13 april 2019.

17 Art. 2, laatste lid Wet 13 april 2019.

18 MvT bij Wetsontwerp van 31 oktober 2018 houdende invoeging van Boek 8 'Bewijs' in het nieuw Burgerlijk Wetboek, Parl. St. 2018-19, nr. 3349/001, p. 3 . 


\subsection{Het toegankelijk maken en codificeren van het geldende recht}

Een eerste hoofdlijn is het toegankelijk maken en codificeren van het geldende recht. Deze hoofdlijn komt vooreerst tot uiting in de bewuste keuze van de wetgever om te starten met een lijst van wettelijke definities (zie par. 3.1.1). Daarnaast codificeert Boek 8 een aantal fundamentele beginselen die sinds enige tijd erkend werden door de rechtspraak en zelfs niet meer ter discussie stonden (zie par. 3.1.2). Ten derde neemt het een aantal bepalingen op die vroeger in een ander wetboek of in een afzonderlijke wet te vinden waren (zie par. 3.1.3).

\subsubsection{Invoering van wettelijke definities}

Net zoals alle andere boekdelen van het BW, start art. 8.1 met een lijst van definities. Enerzijds gaat het om nieuwe definities die vroeger ontbraken in het oud Burgerlijk Wetboek. Anderzijds bevat de lijst ook definities die wél al verspreid stonden over het hoofdstuk bewijs in het oud Burgerlijk Wetboek, maar nu in een eerste bepaling zijn samengebracht en soms in beperkte mate zijn aangepast.

Het meest in het oog springen de algemene functionele definities van het geschrift (art. 8.1, $1^{\circ} \mathrm{BW}$ ) en de handtekening (art. 8.1, $2^{\circ} \mathrm{BW}$ ). $\mathrm{Zij}$ worden voor het eerst ingevoerd. In het verleden ontbrak - net zoals in Nederland - een wettelijke definitie van het geschrift en de handtekening.

Art. 8.1, $1^{\circ} \mathrm{BW}$ definieert een geschrift als 'een geheel van alfabetische tekens of van enige andere verstaanbare tekens aangebracht op een drager die de mogelijkheid biedt toegang ertoe te hebben gedurende een periode die is afgestemd op het doel waarvoor de informatie kan dienen en waarbij de integriteit ervan wordt beschermd, welke ook de drager en de transmissiemogelijkheden zijn'. Deze definitie is gelijkaardig aan de gangbare definitie van een geschrift in de Nederlandse literatuur, namelijk 'iedere drager van verstaanbare leestekens die een gedachte-inhoud vertolken'. ${ }^{19}$ Waar het Nederlandse recht elektronische bewijsmiddelen niet als geschriften beschouwt, maar deze wel op één lijn stelt met geschriften als zij met leestekens leesbaar kunnen worden gemaakt, ${ }^{20}$ maakt het nieuwe Belgische bewijsrecht geen onderscheid meer. De parlementaire voorbereiding verduidelijkt dat art. 8.1, $1^{\circ}$ een open definitie bevat die van toepassing is op iedere vorm van geschrift ongeacht de drager (zoals een document op papier, een e-mail, een sms). ${ }^{21}$ Voorts benadrukt de nieuwe definitie ook het belang van de integriteit van de informatie, zonder daarvoor tot in het extreme te gaan. Zo licht de memorie van toelichting toe dat het mechanisme dat wordt gebruikt om het geschrift te maken, idealiter moet vermijden dat de informatie kan wor-

19 Asser Procesrecht/Asser 3 2017/154; G.R. Rutgers \& H.B. Krans, 'Bewijs', in: Pitlo. Deel 7. Het Nederlands burgerlijk recht, Deventer: Kluwer 2014, p. 102, par. 70.

20 Asser Procesrecht/Asser $32017 / 153$

21 MvT bij Wetsontwerp van 31 oktober 2018 houdende invoeging van Boek 8 'Bewijs' in het nieuw Burgerlijk Wetboek, Parl. St. 2018-19, nr. 3349/001, p. 6. den gewijzigd. Indien dat niet het geval is, moeten de wijzigingen minstens detecteerbaar zijn. Dat moet de opstellers van het geschrift of derden ontraden de informatie te veranderen. ${ }^{22}$ Het praktische belang van de definitie ligt voornamelijk in het feit dat het geschrift een constitutieve voorwaarde uitmakt van een onderhandse akte $\left(\operatorname{art} .8 .1,4^{\circ}\right),{ }^{23}$ een authentieke akte $\left(\text { art. } 8.1,5^{\circ}\right)^{24}$ en een begin van bewijs door geschrift (art. 8.1, $7^{\circ}$ ). De definitie kan dus als leidraad dienen voor de rechter bij het bepalen of een welbepaalde gegevensdrager (bijvoorbeeld een elektronisch platform) in aanmerking komt als een geschrift. Indien dat niet het geval is, kan er ook geen sprake zijn van een onderhandse akte, authentieke akte of begin van bewijs door geschrift. Dit kan ertoe leiden dat de rechter een welbepaalde rechtshandeling niet bewezen verklaart.

Art. 8.1, $2^{\circ}$ BW omschrijft de handtekening als 'een teken of een opeenvolging van tekens, aangebracht met de hand, elektronisch of via ieder ander procedé, waarmee een persoon zich identificeert en waaruit zijn wilsuiting blijkt'. Deze definitie geldt zowel voor de handgeschreven als voor de elektronische handtekening. Zij bevestigt twee basisfuncties van de handtekening: identificatie (het mogelijk maken om de handtekening toe te schrijven aan een persoon) en confirmatie (het uiten van een wil ten aanzien van het ondertekende geschrift). ${ }^{25}$ De wilsuiting zal meestal neerkomen op het instemmen met de inhoud van het geschrift (zoals bij onderhandse en authentieke akten). Toch zijn er ook andere vormen van wilsuiting denkbaar (zoals het tekenen voor ontvangst van een document of het tekenen als getuige om zijn anwezigheid te bevestigen). ${ }^{26}$ Het is opvallend dat in de Nederlandse rechtsleer gelijkaardige functies worden toegeschreven aan de handtekening, zoals het individualiseren van de persoon en het bevestigen van wat boven de handtekening staat. ${ }^{27}$ Het hoeft dan ook niet te verbazen dat de hoogste rechtscolleges van beide rechtsstelsels een paraaf in aanmerking nemen als een handtekening. ${ }^{28}$ Art. 8.1, $2^{\circ}$ laat uitschijnen dat het de ondertekenaar

22 Dat zou het geval zijn voor geschriften op papier. Er kan altijd tekst worden toegevoegd aan of geschrapt in de oorspronkelijke versie van een document op papier, maar de wijzigingen zullen zichtbaar zijn. Hetzelfde geldt bij elektronische geschriften waarbij de wijzigingen misschien niet meteen zichtbaar zijn op het scherm, maar wel in het elektronisch systeem zijn op te sporen (ibid., p. 6).

23 Art. 8.1, $4^{\circ}$ BW definieert een onderhandse akte als 'een geschrift dat rechtsgevolgen beoogt, dat door de partij(en) ondertekend wordt met de bedoeling om met de inhoud ervan in te stemmen, en dat geen authentieke akte is' (curs. WV).

24 Art. 8.1, $4^{\circ} \mathrm{BW}$ definieert een authentieke akte als 'een geschrift dat in de wettelijke vorm is verleden voor een openbare of ministerieel ambtenaar die de bevoegdheid en hoedanigheid heeft om te instrumenteren' (curs. WV).

25 MvT bij Wetsontwerp van 31 oktober 2018 houdende invoeging van Boek 8 'Bewijs' in het nieuw Burgerlijk Wetboek, Parl. St. 2018-19, nr. 3349/001, p. 6.

26 Ibid., p. 7.

27 Asser Procesrecht/Asser 3 2017/160; T.R. Hidma \& G.R. Rutgers, 'Bewijs', in: Pitlo. Deel 7. Het Nederlands burgerlijk recht, Deventer: Kluwer 2004, p. 104 , par. 71.

28 Voor België, zie Cass. 29 september 2014, ECLI:BE:CASS:2014: ARR.20140929.2. Voor Nederland, zie HR 5 oktober 2012, ECLI:NL: HR:2012:BV6698, NJ2012/570, r.o. 3.4. 
zelf is die de handtekening aanbrengt. Op dit punt had de Belgische wetgever - net zoals de parlementaire geschiedenis in Nederland ${ }^{29}$ - ook rekening kunnen houden met de situatie waarbij niet de ondertekenaar zelf de handtekening aanbrengt, maar wel iemand die bevoegd is dat namens hem te doen. Op die manier had de vaak voorkomende praktijk waarbij een medewerker een gescande handtekening integreert in een pdf, een juridische onderbouwing gekregen.

Aansluitend op de algemene definitie van de handtekening bevat Boek 8 een bijkomende definitie voor de elektronische handtekening in art. 8.1, $3^{\circ}$, die een loutere verwijzing uitmaakt naar art. 3.10 tot 3.12 van Verordening nr. 910/2014. De artikelen waarnaar wordt verwezen, definiëren drie types elektronische handtekeningen in functie van het niveau van beveiliging: de (gewone) elektronische handtekening, de geavanceerde en de gekwalificeerde elektronische handtekening. Een equivalent van art. 3:15a van het Nederlandse Burgerlijk Wetboek, dat de voorwaarden bepaalt waaraan een geavanceerde elektronische handtekening en een (gewone) elektronische handtekening moeten voldoen om dezelfde rechtsgevolgen te hebben als een handgeschreven handtekening, is in België niet te vinden..$^{30}$ In België zal de rechter voor ieder type handtekening de functionele vereisten van art. $8.1,2^{\circ} \mathrm{BW}$ moeten aftoetsen. Indien de handtekening daaraan voldoet, kan zij rechtsgevolgen teweegbrengen.

Vervolgens bevat art. $8.1 \mathrm{BW}$ de definities van de vijf bewijsmiddelen die reeds werden geregeld door het Burgerlijk Wetboek van 1804, te weten de onderhandse akte en authentieke akte (art. 8.1, $4^{\circ}$ en $\left.5^{\circ}\right),{ }^{31}$ de getuigenis $\left(\right.$ art. 8.1, $8^{\circ}$ ), het feitelijk vermoeden (art. 8.1, $9^{\circ}$ ), de bekentenis (art. 8.1, 10 $0^{\circ}$ ) en de eed (art. 8.1,12 ${ }^{\circ}$ ), net zoals de omschrijving van een aantal concepten die nauw verband houden met die bewijsmiddelen, zoals het begin van bewijs door geschrift (art. 8.1, $7^{\circ}$ ), de samengestelde bekentenis ( $\operatorname{art} .8 .1,11^{\circ}$ ) en de toelaatbaarheid (art. 8.1, $\left.13^{\circ}\right)$.

Twee kernbegrippen uit het bewijsrecht sluiten de lijst van definities af: bewijswaarde en wettelijke bewijswaarde.

Bewijswaarde (art. 8.1, $14^{\circ} \mathrm{BW}$ ) wijst op 'de mate waarin een bewijselement de rechter overtuigt'. Heel wat bewijsmiddelen (zoals het getuigenbewijs en de feitelijke vermoedens) hebben een vrije bewijswaarde. Dit betekent dat de rechter soeverein kan oordelen of hij geen, weinig of veel geloofwaardigheid aan dit specifieke bewijsmiddel zal hechten. Het Nederlandse recht verwijst in dat verband eerder naar de (vrije) bewijs-

29 G.R. Rutgers \& R.J.C. Flach, Parlementaire geschiedenis van de nienwe regeling van het bewijsrecht in burgerlijke zaken, Deventer: Kluwer 1988, p. 151.

30 Deze bepaling heeft evenwel al anleiding gegeven tot rechtspraak van de Hoge Raad (HR 14 juni 2019, ECLI:NL:HR:2019:957, NJ 2021/14, m.nt. A.I.M. van Mierlo) en is aan kritiek onderhavig (zie T.H.M. van Wechem \& J.H.M. Spanjaard, 'Hoe houdbaar is de handtekening in een pdf-document?', Contracteren 2019, afl. 4, p. 123-127).

31 Beide akten maken een ondertekend geschrift uit (art. 8.1, $6^{\circ} \mathrm{BW}$ ). kracht. ${ }^{32}$ In Nederland hebben alle bewijsmiddelen in principe bewijskracht, met uitzondering van de bewijsmiddelen waarvoor de wet, de partijen of de rechter in het algemeen of in concrete omstandigheden het bewijs uitsluiten. In dat geval hebben die bewijsmiddelen geen enkele bewijskracht in het proces. ${ }^{33}$

In het Belgische recht betekent bewijkkracht iets anders. Bepaalde auteurs kennen er zelfs twee betekenissen aan toe. ${ }^{34}$ In een eerste betekenis ('force probante') zou het gaan om de wettelijk opgelegde of verplichte bewijswaarde van de toegelaten bewijsmiddelen. Om elke verwarring te voorkomen, verdient het aanbeveling om hiervoor de term 'wettelijke bewijswaarde' te gebruiken. Dat is trouwens ook de keuze die de Belgische wetgever heeft gemaakt bij de invoering van Boek 8 (zie infra). De tweede betekenis ('la foi due aux actes') houdt verband met de inhoud zelf van het aangevoerde bewijsmiddel. Indien de inhoud van een geschrift onduidelijk is en er hierover betwisting ontstaat tussen de partijen, dan zal de rechter de inhoud van die akte moeten interpreteren. Volgens de hoofdregel uit art. 1156 oud BW moet hij daarbij nagaan wat de gemeenschappelijke bedoeling van de partijen is geweest. Aangezien het vaststellen van de bedoeling van de partijen een feitenkwestie betreft, behoort de interpretatie in principe tot de soevereine appreciatie van de feitenrechter. ${ }^{35}$ Toch is de interpretatievrijheid van de rechter niet onbegrensd. Zo mag hij aan een akte geen uitlegging geven die niet verenigbaar is met de bewoordingen ervan. ${ }^{36} \mathrm{Er}$ is sprake van een schending van de bewijskracht wanneer de rechter de akte doet liegen. ${ }^{37}$ Dat is het geval wanneer hij er iets in leest wat er niet in te vinden is of ontkent wat er duidelijk wel in staat. De bewijkkracht is niet gedefinieerd in art. $8.1 \mathrm{BW}$, angezien dit begrip verder ook niet opduikt in Boek 8 .

Ten slotte heeft een beperkt aantal bewijsmiddelen in België een wettelijke bewijswaarde (art. 8.1, 15 $\mathrm{BW}$ ). In dat geval levert 'een bewijsmiddel volgens de wet bewijs [op] en [zijn] de rechter en de partijen door dit bewijsmiddel gebonden'. In het burgerlijk bewijsrecht hebben de onderhandse akte, de authentieke akte, de bekentenis en de gedingbeslissende eed een wettelijke bewijswaarde. In de meeste gevallen sluit de wettelijke bewijswaarde niet uit dat er nog tegenbewijs wordt geleverd. Enkel bij de gedingbeslissende eed is ieder tegenbewijs

32 Zie o.m. Asser Procesrecht/Asser 3 2017/53; Beenders, in: TGंC Burgerlijke rechtsvordering 2021, art. 151, aant. 1.

33 Asser Procesrecht/Asser 3 2017/257.

34 B. Cattoir, 'Burgerlijk bewijsrecht', in: APR, Mechelen: Kluwer 2013, p. 127, nr. 246; B. Krans \& P. Taelman, 'Partijgetuigen in het civiele recht: België en Nederland', in: W. van Boom e.a. (red.), Een kwart eenw - privaatrechtelijke opstellen aangeboden aan prof. mr. H.J. Snijders ter gelegenheid van zijn emeritaat, Deventer: Wolters Kluwer 2016, p. 273.

35 S. Stijns, Leerboek verbintenissenrecht, I, Brugge: die Keure 2016, p. 60, nr. 77.

36 Zie o.m. Cass. 23 oktober 2009, ECLI:BE:CASS:2009: ARR.20091023.8; Cass. 11 september 2006, ECLI:BE:CASS:2006: ARR.20060911.6.

37 B. Samyn, Privaatrechtelijk bewijs, een diepgaand en praktisch overzicht, Gent: Story-Publishers 2012, p. 52; S. Stijns, Verbintenissenrecht, I, Brugge: die Keure 2016, p. 60. 
uitgesloten. Het begrip wettelijke bewijswaarde vertoont enige gelijkenissen met het dwingend bewijs in Nederland, waarvan onder meer sprake is bij een authentieke akte (art. $157 \mathrm{Rv}$ ) of bij een strafvonnis (art. $161 \mathrm{Rv).} \mathrm{Ook} \mathrm{bij} \mathrm{dwingend} \mathrm{bewijs}$ staat tegenbewijs praktisch altijd open. ${ }^{38}$

\subsubsection{Codificatie van het geldende recht}

Zoals hoger vermeld, bestaat Boek 8 'Bewijs' uit drie hoofdstukken. In elk van die hoofdstukken zijn er heel wat codificaties te vinden van in de Belgische rechtspraak aanvaarde oplossingen. Hier beperk ik mij tot een bespreking van de codificatie van twee fundamentele beginselen in het hoofdstuk met de algemene bepalingen.

Vooreerst bevestigt Boek 8 als algemene regel dat alle regels van aanvullend recht zijn, behoudens de definities en behalve in de gevallen waarin de wet anders bepaalt (art. 8.2 BW). Het staat partijen dus steeds vrij om een bewijsovereenkomst aan te gaan, tenzij de wet uitdrukkelijk bepaalt dat iedere overeenkomst die afwijkt van de desbetreffende bewijsregel nietig is (zie art. 8.11, $\$ 4$, tweede lid, 8.17 en $8.11, \$ 4$, tweede lid BW). Anders dan art. $153 \mathrm{Rv}$ in Nederland, bestaat er geen specifieke regel die de bewijsovereenkomst beperkt tot feiten die ter vrije bepaling van de partijen staan. Niettemin zou het in België evenmin mogelijk zijn om een bewijsovereenkomst af te sluiten over feiten waaraan het recht gevolgen verbindt die niet ter vrije bepaling van de partijen staan of die ingaan tegen andere dwingende rechtsregels. ${ }^{39}$

Daarnaast verankert Boek 8 het geldende recht inzake het voorwerp van het bewijs. Dat is de vraag wat er bewezen moet worden. Luidens art. 8.3 BW moeten 'feiten of rechtshandelingen worden bewezen wanneer ze aangevoerd en betwist zijn'. Algemeen bekende feiten (zoals de schadelijkheid van asbest ${ }^{40}$ of ervaringsregels (zoals het typische verloop van de gebeurtenissen $)^{41}$ moeten niet worden bewezen. Met deze bepaling vindt het Belgische recht aansluiting bij art. 149 Rv.

\subsubsection{Concentratie van bewijsregels}

Boek 8 brengt een aantal bewijsregels samen die voordien verspreid stonden in afzonderlijke wetten of andere wetboeken. Art. 8.23 BW integreert vooreerst de regeling inzake de advocatenakte in het Burgerlijk Wetboek. De advocatenakte is een uit Frankrijk overgenomen mechanisme $e^{42}$ dat werd ingevoerd bij wet van 29 april $2013 .{ }^{43}$ Het systeem bestaat erin dat partijen een onderhandse akte afsluiten en die laten medeondertekenen door hun raadsman (ar. 8.23, eerste lid). De advocaten-

38 Asser Procesrecht/Asser $32017 / 257$.

39 B. Allemeersch \& W. Vandenbussche, 'De rol van de rechter bij bewijsafspraken tussen de partijen', in: S. Stijns \& P. Wéry, De rol van de rechter in het contract, Brugge: die Keure 2014, p. 168, nr. 41.

40 Rb. Leuven 12 oktober 1999, TMR 2000, 338, m.nt. E. De Kezel.

41 W. Vandenbussche, Bewijs en onrechtmatige daad, Antwerpen: Intersentia 2017, p. 475, nr. 553.

42 Art. 66-3-1 e.v. van 'la loi no 71-1130 du 31 décembre 1971 portant réforme de certaines professions judiciaires et juridiques'.

43 Wet van 29 april 2013 betreffende de door de advocaten van de partijen medeondertekende onderhandse akte, BS 3 juni 2013. akte levert een volledig bewijs op van het geschrift en de handtekening van de betrokkenen en kan enkel worden betwist door middel van een valsheidsprocedure (ar. 8.23, tweede lid). ${ }^{44}$ De advocatenakte heeft de voorbije acht jaar weinig tot zelfs geen ingang gevonden in de Belgische rechtspraktijk. Een van de redenen is het ontbreken van uitvoerbare kracht. Het is hoogst twijfelachtig of de opname in het Burgerlijk Wetboek daar iets aan zal veranderen.

Belangrijker is dat Boek 8 ook de regels inzake het ondernemingsbewijs in het Burgerlijk Wetboek integreert in art. 8.11. Het begrip ondernemingsbewijs klinkt de Nederlandse jurist misschien niet zo bekend in de oren, maar in België maakt men net zoals in Frankrijk sinds lang een onderscheid tussen enerzijds het burgerlijke bewijsrecht en anderzijds het ondernemingsbewijsrecht. ${ }^{45}$ Voor het bewijs van rechtshandelingen tussen of tegen particulieren (dat wil zeggen niet-ondernemingen) geldt het gereglementeerde of wettelijke bewijsstelsel (zie infra, par. 3.2.1). Het ondernemingsbewijsrecht wordt daarentegen gekenmerkt door een grotere vrijheid. Ongeacht de waarde van de rechtshandeling en zelfs boven of tegen de inhoud van akten kunnen partijen gebruik maken van alle bewijsmiddelen die zij wensen (zoals e-mails, brieven of getuigenverklaringen). Daarnaast kunnen de hoven en rechtbanken de bewijswaarde van de aangebrachte bewijsmiddelen vrij waarderen. Het eerste lid van art. 8.11, $₫ 1$ luidt dan ook als volgt:

'Bewijs kan tussen ondernemingen of tegen ondernemingen, zoals omschreven in artikel I.1, eerste lid van het Wetboek economisch recht worden geleverd door alle bewijsmiddelen.'

De grotere vrijheid van bewijs in ondernemingszaken heeft historische wortels. De meeste handelstransacties werden vroeger op beurzen en markten gesloten, meestal door analfabeten die wisten dat ze op het gegeven woord van hun contractpartner konden vertrouwen. ${ }^{46}$ Hoewel de praktijken van het ondernemingsleven in aanzienlijke mate zijn geëvolueerd,

44 Zie o.m. Y. Kevers, 'L'acte avocat', JT 2013, p. 357-361; S. Roeland, 'De onderhandse akte die is medeondertekend door de advocaten van de partijen: een karakterschets', T.Not. 2013, p. 595-602.

45 Tot voor kort sprak men over handelsbewijs. De wet van 15 april 2018 houdende hervorming van het ondernemingsrecht (BS 27 april 2018) ontdeed zich echter van het begrip handelaar en verving het door het ruimere begrip onderneming. Sindsdien hanteert het Belgische recht de kwalificatie van onderneming in de zin van art. I.1, $1^{\circ}$ Wetboek economisch recht als onderscheidend criterium. Dat is niet alleen het geval in het bewijsrecht, maar ook bijvoorbeeld bij het bepalen van de bevoegdheid van de rechtbanken en de toepassing van de faillissementswetgeving. Nieuwe categorieën die vroeger geen handelaar waren, maar nu wel een onderneming zijn onder meer de vrije beroepers, de verenigingen zonder winstoogmerk en de landbouwers.

46 R. Jaferali, 'La liberté de la preuve en matière commerciale, spécialement de la transaction' (noot onder Cass. 19 maart 2012), RCJB 2014, p. 666, nr. 6; L. Waelkens, 'Geschiedenis van het handelsrecht', in: G. Ballon e.a. (red.), Beginselen van Belgisch privaatrecht, XIII. Handels-en economisch recht, deel 1. Ondernemingsrecht, vol. A, Mechelen: Kluwer 2011, p. 3, nr. 14. 
huldigde de Belgische wetgever bij de invoering van Boek 8 nog steeds het principe van het vrije bewijs. De redenen hiervoor zijn onder meer de snelheid, voortvarendheid en het pragmatisme van het bedrijfsleven, de idee dat ondernemingen minder nood zouden hebben aan bescherming (in vergelijking met consumenten) en het feit dat ondernemingen een boekhouding bijhouden (waardoor iedere transactie sowieso een schriftelijke neerslag krijgt). ${ }^{47}$

Verder bevat art. 8.11 BW ook nog specifieke regels inzake twee ondernemingsrechtelijke bewijsmiddelen: de boekhouding $(\$ 2$ en 3$)$ en de factuur $(\$ 4)$. Luidens art. 8.11, $\$ 3 \mathrm{kan}$ de rechter op verzoek of ambtshalve in de loop van een geding de overlegging bevelen van het geheel of van een gedeelte van de boekhouding van een onderneming betreffende het te onderzoeken geschil. De rechter kan daarbij maatregelen opleggen om de vertrouwelijkheid van de desbetreffende stukken te vrijwaren. Deze bepaling stemt in grote mate overeen met art. 162 Rv. Anders dan het tweede lid van art. $162 \mathrm{Rv}$ verduidelijkt art. 8.11, $\$ 3$ niets over de gevolgtrekking die de rechter kan afleiden uit de weigering om aan een bevel tot overlegging te voldoen. Niettemin zou een Belgische rechter een feitelijk vermoeden kunnen aannemen dat de inhoud van de boekhouding in overeenstemming is met de aanvoeringen van de verzoekende partij. In bepaalde gevallen zou hij zelfs kunnen overgaan tot een omkering van het bewijsrisico. ${ }^{48}$ Voorts illustreert art. 8.11, $₫ 3$ dat de tweedeling tussen de materiële regels in het Burgerlijk Wetboek en de formele regels in het Gerechtelijk Wetboek niet consequent is (zie ook supra). De overlegging van de boekhouding is een onderzoeksmaatregel, die de parlementaire voorbereiding zelf aanduidt als een specificatie van de algemene regel uit het Gerechtelijk Wetboek. ${ }^{49}$ Het zou dan ook logischer zijn geweest om deze bepaling tussen de procedureregels in dat wetboek op te nemen.

\subsection{Het bevestigen van het gereglementeerde bewijsstelsel, maar met versoepeling van het bewijsformalisme}

Een belangrijke keuze waar de Belgische wetgever voor stond, was het behoud of de afschaffing van het gereglementeerde bewijsstelsel in burgerlijke zaken, meer bepaald voor het bewijs van rechtshandelingen tussen of tegen particulieren (dat wil zeggen niet-ondernemingen). Een gereglementeerd of wettelijk bewijsstelsel houdt in dat de wet op voorhand bepaalt welke bewijsmiddelen in welke omstandigheden toelaatbaar zijn (bijvoorbeeld via het vereisen van een ondertekend geschrift voor rechtshandelingen boven een bepaalde waarde). Ieder bewijselement dat een partij naar voren wil brengen, moet binnen een abstracte categorie van bewijsmiddelen worden geplaatst. Bovendien hebben bepaalde bewijsmiddelen een

47 L. Debroux \& G. Fruy, 'La preuve contre les entreprises', in: D. Mougenot (red.), La réforme du droit de la preuve, Liège: Anthemis 2019, p. 151-152, nr. 4.

48 W. Vandenbussche \& M. Van de Looverbosch, 'Ondernemingsbewijsrecht', in: D. Van Gerven \& J. Vananroye (red.), Leerstukken ondernemingsrecht, Antwerpen: Intersentia 2020, p. 127-128.

49 MvT bij Wetsontwerp houdende hervorming van het ondernemingsbewijsrecht, Parl. St. 2017-18, nr. 2828/001, p. 46. wettelijke bewijswaarde (bijvoorbeeld onderhandse en authentieke akten), wat betekent dat de rechter en de partijen verplicht zijn om deze bewijsmiddelen te aanvaarden, desgevallend behoudens tegenbewijs.

Nederland maakte met de invoering van het nieuwe bewijsrecht in 1988 reeds een einde aan het gereglementeerde bewijsstelsel. ${ }^{50} \mathrm{Er}$ is sindsdien geen opsomming meer van de bewijsmiddelen, het bewijs kan worden geleverd met alle bewijsmiddelen (art. 152 eerste lid Rv) en de waardering van het bewijs is aan het oordeel van de rechter overgelaten (art. 152, eerste lid $\mathrm{Rv})$. België kiest daarentegen in Boek 8 voor het behoud van het gereglementeerde bewijsstelsel. Het volgt daarmee het voorbeeld van Frankrijk, dat bij zijn hervorming in 2016 ook heeft vastgehouden aan dit bewijsstelsel. Er is dus geen veralgemeende toepassing van het vrije bewijs in België. Hoewel dat vroeger reeds aanvaard werd, wordt nu duidelijker in de verf gezet dat het vrije bewijsstelsel geldt voor het bewijs van feiten (art. 8.9 BW). In het buitencontractueel aansprakelijkheidscontentieux en in de andere gevallen waarin het bewijsdebat (deels) betrekking heeft op feiten, kunnen partijen dus wel gebruik maken van alle mogelijke bewijsmiddelen. Zoals hoger vermeld, geldt het vrije bewijsstelsel ook voor het bewijs tussen en tegen ondernemingen (art. 8.11 BW). Het toepassingsgebied van het gereglementeerde bewijsstelsel is dus beperkt tot het bewijs van rechtshandelingen tussen en tegen particulieren (dat wil zeggen niet-ondernemingen), zoals onder meer de verkoop aan een consument of een lening tussen kennissen.

De memorie van toelichting duidt als reden voor het behoud van het gereglementeerde bewijsstelsel aan dat er in de recente rechtsleer geen voorstellen te vinden waren om dit stelsel af te schaffen. ${ }^{51}$ Dat is niet bijzonder overtuigend. Eerder dan te verwijzen naar het ontbreken van voorstellen in de rechtsleer, had de opsteller van de memorie van toelichting beter duidelijker positie ingenomen over de achterliggende beweegredenen van deze regeling. Het rapport bij het Franse hervormingsvoorstel biedt iets meer inzage in de motieven voor het behoud van het gereglementeerde bewijsstelsel. De Franse wetgever zou dat voor de veiligheid van transacties noodzakelijk hebben geacht, aangezien de loutere wilsovereenstemming in principe al volstaat voor de totstandkoming van een overeenkomst. ${ }^{52}$ Het lijkt erop dat de Belgische wetgever via het gereglementeerde bewijsstelsel eveneens het gedrag van partijen wil beïnvloeden. Het bestaan van het gereglementeerde bewijsstelsel kan hen er namelijk toe aanzetten om hun afspraken op een ondertekend geschrift te zetten. Hebben de partijen hun afspraken eenmaal in een ondertekend geschrift vastgelegd, dan

50 Zie o.m. Rutgers \& Krans 2014, p. 6.

51 MvT bij Wetsontwerp van 31 oktober 2018 houdende invoeging van Boek 8 'Bewijs' in het nieuw Burgerlijk Wetboek, Parl. St. 2018-19, nr. 3349/001, p. 4.

52 Rapport au Président de la République relatif à l'ordonnance $n^{\circ} 2016$ 131 du 10 février 2016 portant réforme du droit des contrats, du régime général et de la preuve des obligations, JORF n 0035 du 11 février 2016, www.legifrance.gouv.fr/eli/rapport/2016/2/11/JUSC1522466P/jo/ texte, p. 31-32. 
heeft dat een aantal gevolgen. Vooreerst zou het de kans verkleinen dat nadien een betwisting rijst over deze rechtshandeling. Daarnaast zou de rechtshandeling bij een betwisting of niet-nakoming door een van de partijen vlotter afdwingbaar zijn door de aanwezigheid van een ondertekend geschrift. Ten slotte kan het personen tegen zichzelf beschermen, omdat zij moeten voldoen aan bepaalde vereisten bij het aangaan van belangrijke engagementen. ${ }^{53}$

Er is natuurlijk een keerzijde aan dit verhaal. Ontstaat eenmaal een juridisch geschil, dan zullen partijen beperkt zijn op het vlak van de bewijsmiddelen die zij kunnen aanwenden. Daarnaast is het niet voor alle particulieren even evident om hun afspraken op ondubbelzinnige wijze op papier te zetten. Ook de rechter zal op zijn beurt belemmeringen ondervinden bij zijn bewijsoordeel..$^{54}$ Wanneer het aangevoerde bewijs bijvoorbeeld aantoont dat er sprake is van een overeenkomst, maar dit bewijs niet kwalificeert als een ondertekend geschrift, en een van de uitzonderingen op de vereiste van een geschrift is niet van toepassing, dan zal de rechter de overeenkomst niet bewezen mogen verklaren. Op die manier ontstaat er een schisma tussen de werkelijke en de juridische waarheid, wat niet bevorderlijk is voor het vertrouwen van de rechtszoekende. Het doet sommigen besluiten dat het Belgische bewijsrecht 'de rechters doet spreken met een gespleten tong. ${ }^{55}$ Voorts geeft de toepassing van het gereglementeerde bewijsstelsel onvermijdelijk aanleiding tot discussies in de rechtbank. Asser bekritiseert in dat verband de grote hoeveelheid rechtspraak in Frankrijk omtrent de uitleg en het werkingsgebied van deze regels. ${ }^{56}$ In België bestaat eveneens een aanzienlijk corpus aan rechtspraak over deze kwestie. ${ }^{57}$ Aldus rijst de vraag of de rechter zijn schaarse tijd niet in andere zaken moet investeren. Een laatste mogelijk bezwaar is dat de keuze voor het gereglementeerde bewijsstelsel lijkt te steunen op de assumptie dat particulieren hun afspraken in een ondertekend geschrift opnemen omdat zij zich bewust zijn van deze regels. Het is maar de vraag in welk percentage van de gevallen dit zo is. Voor zover ik heb kunnen nagaan, is daarover in België noch in Frankrijk enig onderzoek verricht.

De houdbaarheid van het gereglementeerde bewijsstelsel is dus een uiterst moeilijke kwestie, die een genuanceerd debat verdient. Idealiter zou er empirisch bewijs moeten anwwezig zijn over het gedrag van rechtszoekenden. De verantwoording van de Belgische wetgever in de parlementaire voorbereiding van Boek 8 is op dat punt dus ontoereikend.

53 Zie in dat verband Samoy \& Vandenbussche 2019, p. 134, nr. 29.

54 Vgl. Asser Procesrecht/Asser $32017 / 53$.

55 S. Stijns, 'Gedrag en wangedrag', $R W$ 1989-1990, p. 1004, nr. 3.

56 Asser Procesrecht/Asser 3 2017/53: 'Het laat zien dat in deze tijd een systematische hiërarchie van bewijsmiddelen die is gebaseerd op a priori aangenomen (on)betrouwbaarheid van bewijsmiddelen (met name schriftelijk bewijs versus getuigenbewijs) niet meer vanzelf spreekt.'

57 B. Allemeersch, I. Samoy \& W. Vandenbussche, 'Overzicht van rechtspraak: het burgerlijk bewijsrecht (2000-2013)’, TPR 2015, p. 906-946.

\subsubsection{Het principe}

De kernbepaling van het Belgische gereglementeerde bewijsstelsel is art. 8.9, $\$ 1$, eerste lid BW:

'De rechtshandeling met betrekking tot de som of een waarde die gelijk is aan of hoger is dan 3.500,00 euro, moet door de partijen worden bewezen door een ondertekend geschrift. (...) Het bewijs boven of tegen een ondertekend geschrift kan enkel worden geleverd door een ander ondertekend geschrift, zelfs indien de som of de waarde dat bedrag niet te boven gaat.'

\section{Daarnaast bepaalt het tweede lid van art. $8.9, \S 1$ :}

'Dat bedrag kan worden aangepast bij een koninklijk besluit vastgesteld na overleg in de Ministerraad in het licht van de evolutie van de levenskosten of de sociale noden.'

De wijziging van het plafond door de uitvoerende macht maakt een soepelere evolutie mogelijk. Zij wordt ook reeds toegepast in Frankrijk en in het Groothertogdom Luxemburg $^{58}$ en werd gesuggereerd door de rechtsleer sedert 1991.59

In het verleden bedroeg de drempel voor het vereisen van een ondertekend geschrift $€ 375$. Met de invoering van Boek 8 heeft de Belgische wetgever dit plafond aanzienlijk opgetrokken. Dit betekent dat voor veel dagdagelijkse en courante rechtshandelingen sinds 1 november 2020 het vrije bewijs geldt. Dit moet burgers aanmoedigen om in rechte op te treden en verkleint de hindernis van het gereglementeerde bewijsstelsel in kleine dossiers. ${ }^{60}$ Met het vastleggen van de drempel op $€ 3500$ ligt deze nu hoger dan in Frankrijk (€ 1500) en het Groothertogdom Luxemburg (€2500).

Art. 8.9 BW bevat daarnaast nog drie regels ter verduidelijking van het uitgangspunt. De waarde die in rekening moet worden genomen, is deze van de rechtshandeling die ten grondslag ligt aan de vordering (art. 8.9, \$2). Wanneer een partij nog een openstaande vordering heeft die lager is dan de drempelwaarde (bijvoorbeeld van € 2000), maar deze deel uitmaakt van een omvangrijkere rechtshandeling (bijvoorbeeld ter waarde van $€ 50.000$ ), dan moet deze openstaande vordering bewezen worden via een ondertekend geschrift. ${ }^{11}$ Voor duurcontracten is er ook een specifieke toelichting. Het gaat om de totale waarde van de vergoedingen van de prestaties voor een maximale duur van één jaar (art. 8.9, §3). Ten slotte is er een uitzondering wanneer de waardering van het voorwerp van de handeling onmogelijk is, omdat de waarde niet bepaald is of bepaalbaar is bij het ontstaan van de rechtshande-

58 MvT bij Wetsontwerp van 31 oktober 2018 houdende invoeging van Boek 8 'Bewijs' in het nieuw Burgerlijk Wetboek, Parl. St. 2018-19, nr. 3349/001, p. 19.

59 N. Verheyden-Jeanmart, Droit de la preuve, Brussel: Larcier 1991, p. 153154, nr. 314.

60 MvT bij Wetsontwerp van 31 oktober 2018 houdende invoeging van Boek 8 'Bewijs' in het nieuw Burgerlijk Wetboek, Parl. St. 2018-19, nr. 3349/001, p. 18-19. 
ling. In dat geval mag het bewijs worden geleverd met alle bewijsmiddelen (art. 8.9, $\$ 4$ ).

Twee uitzonderingen op het vereiste van een bewijs door ondertekend geschrift, die reeds bestonden onder het oud Burgerlijk Wetboek, blijven behouden. Vooreerst bevestigt art. 8.12 de uitzondering bij onmogelijkheid om te bewijzen. Meer bepaald hoeft een partij geen ondertekend geschrift voor te leggen 'in geval van materiële of morele onmogelijkheid zich een akte te verschaffen of indien het gebruikelijk is geen akte op te stellen. Hetzelfde geldt wanneer de akte verloren is gegaan door overmacht'. Daarnaast kan het ondertekend geschrift worden vervangen door een bekentenis, een beslissende eed of een aangevuld begin van bewijs door geschrift (art. 8.13). Een begin van bewijs is elk geschrift dat uitgaat van degene die een rechtshandeling betwist of van degene die hij vertegenwoordigt, en waardoor de aangevoerde rechtshandeling waarschijnlijk wordt gemaakt (art. 8.1, $7^{\circ}$ ). Het gaat dan bijvoorbeeld om een sms-bericht, een kopie van een onderhandse akte of een bankuittreksel. Aangezien er geen sprake is van een ondertekend geschrift dat aan alle vereisten voldoet, moet het begin van bewijs naderhand worden aangevuld met bijvoorbeeld een getuigenis of een vermoeden. De idee is dat het moet worden aangetoond dat de partij na het begin van bewijs nog steeds zinnens was om de rechtshandeling aan te gaan.

\subsubsection{Versoepelingen van het bewijsformalisme}

Niettemin was het ook de wens van de wetgever om het bewijsformalisme te versoepelen. Daarom roept Boek 8 nog bijkomende uitzonderingen op het gereglementeerde bewijsstelsel in het leven. Zo schrijft art. 8.10 BW voor dat het vrije bewijs geldt voor eenzijdige rechtshandelingen. Voor het bewijs van de betaling is dat een opvallende breuk met het verleden. In het verleden bestond er in België overeenstemming dat een betaling een eenzijdige rechtshandeling was, die in overeenstemming met art. 1341 oud Burgerlijk Wetboek moest worden bewezen. ${ }^{61}$ Voor bedragen boven de $€ 375$ hadden partijen in principe steeds een kwijting nodig. Onder het nieuwe bewijsrecht kan de betaling worden bewezen met alle bewijsmiddelen.

Er bestaat wel een belangrijke beperking op deze uitzondering voor eenzijdige rechtshandelingen ten gunste van de hoofdregel. Een rechtshandeling houdende een eenzijdige verbintenis tot betalen kan enkel worden bewezen met een geschrift dat 'de handtekening bevat van de persoon die zich verbindt, alsmede de vermelding, door hemzelf geschreven, van de som of van de hoeveelheid voluit in letters uitgedrukt' (art. 8.21 BW). Een gelijkaardige formaliteit is in het Nederlandse bewijsrecht te vinden voor verbintenissen van één partij die strekken tot voldoening van een geldsom. Uit art. 158, eerste lid $\mathrm{Rv}$ volgt dat de onderhandse akte die dergelijke verbintenissen bevat 'geheel met de hand is geschreven of voorzien is van een goed-

61 Cass. 6 december 2002, ECLI:BE:CASS:2002:ARR.20021206.4. keuring die de geldsom voluit in letters vermeldt'. Deze regel is vergelijkbaar met de voorschriften van het oud Burgerlijk Wetboek. Onder het vroegere regime was het in België vereist dat de akte ofwel geheel met de hand was geschreven, ofwel ten minste naast de handtekening een handgeschreven 'goed voor' of een 'goedgekeurd voor' bevatte, waarbij de som of de hoeveelheid van de zaak voluit in letters was uitgedrukt. ${ }^{62}$ In het nieuwe art. 8.21 is het vereiste van een handgeschreven 'goed voor' of 'goedgekeurd voor' verdwenen. Op die manier heeft de Belgische wetgever geprobeerd om een evenwicht te bewerkstelligen tussen het behouden van enig formalisme in het licht van de bescherming van zwakkere partijen en het versoepelen van de bewijsvereisten. Het normdoel van art. 8.21 is een partij twee keer te doen nadenken alvorens een eenzijdige verbintenis of eenzijdige overeenkomst tot betaling aan te gaan. De wetgever wil haar beschermen tegen de ondertekening van schuldbekentenissen waarvan zij het bedrag niet beseft of waarvan het bedrag later aangepast kan worden. ${ }^{63} \mathrm{Om}$ dat normdoel te bereiken, is de toevoeging 'goed voor' of 'goedgekeurd voor' niet absoluut noodzakelijk. ${ }^{64}$ De nieuwe Belgische formulering kan misschien ter inspiratie dienen voor het Nederlandse recht, aangezien de verwachting dat een onderhandse akte geheel met de hand geschreven is niet meer overeenstemt met de huidige praktijken.

\subsection{Het bewijsrecht aanpassen aan de moderne samenleving}

\subsubsection{Het schrappen van archaïsche bewijsmiddelen}

De aanpassing van het bewijsrecht aan de moderne samenleving gebeurde vooreerst door het schrappen van een aantal archaïsche bewijsmiddelen (zoals kerven, huishoudelijke registers en akten van erkenning). Een - nochtans eveneens in onbruik geraakt - bewijsmiddel dat de moderniseringsoperatie wel heeft doorstaan, is de gedingsbeslissende eed. Deze wordt in de loop van een geding door de ene partij aan de andere - of ambtshalve door de rechter - opgedragen om de oplossing van het geding daarvan te laten afhangen (art. 8.33 BW). Die partij zal dan een plechtige verklaring afleggen waarbij zij de waarachtigheid van haar beweringen bevestigt (art. 8.1, $9^{\circ} \mathrm{BW}$ ). Indien zij een dergelijke verklaring aflegt, is het geschil op dat punt definitief in haar voordeel beslecht. De gedingbeslissende eed heeft dus een wettelijke en afdoende bewijswaarde en biedt de rechter geen appreciatiemarge (art. 8.37 BW).

62 Art. 1326 oud BW luidde als volgt: 'een onderhands biljet of een onderhandse belofte waarbij een enkele partij zich tegenover de andere verbindt om haar een geldsom of een waardeerbare zaak te betalen, moet geheel geschreven zijn met de hand van de ondertekenaar of tenminste moet deze, benevens zijn handtekening, met de hand een goed voor of een goedgekeurd voor geschreven hebben, waarbij de som of de hoeveelheid van de zaak voluit in letters is uitgedrukt'.

63 Samoy \& Vandenbussche 2019, p. 140, nr. 42.

64 MvT bij Wetsontwerp van 31 oktober 2018 houdende invoeging van Boek 8 'Bewijs' in het nieuw Burgerlijk Wetboek, Parl. St. 2018-19, nr. 3349/00, p. 30 
De belangrijkste tegenwerping tegen de gedingbeslissende eed is dat er geen bewijs wordt geleverd, maar slechts een bevestiging wordt gegeven door de partij zelf. Het gaat dus niet zozeer om een bewijsmiddel, maar om een manier om een einde te stellen aan het geding. ${ }^{65}$ Vroeger ontleende de eed zijn bijzondere waarde aan het beroep op het goddelijke. In de huidige lekenmaatschappij lijkt de gedingbeslissende eed eerder een anachronisme binnen het proces- en bewijsrecht. Zo is de decisoire eed sinds geruime tijd uit het Nederlandse recht verdwenen. Bovendien kwam de eed in de praktijk uiterst zelden voor onder de gelding van het Burgerlijk Wetboek van 1804. ${ }^{66}$ Niets wijst erop dat dit in de toekomst anders zou zijn. Niettemin wilde de Belgisch wetgever de rechter en de partijen de mogelijkheid niet ontnemen om gebruik te maken van de eed. Bovendien zouden ook andere bepalingen in het oud Burgerlijk Wetboek nog steeds naar de eedaflegging verwijzen (bijvoorbeeld art. $1715 \mathrm{BW}$ inzake huur en art. $2275 \mathrm{BW}$ in het kader van de toepassing van de korte verjaringstermijnen op grond van een vermoeden van betaling), hoewel dat argument niet bijzonder overtuigend is.

\subsubsection{Het aanpassen aan technologische ontwikkelingen}

Door het schrappen van archaïsche bewijsmiddelen creëerde de Belgische wetgever als het ware ruimte in het wetboek voor digitale bewijsmiddelen. Toch opteerde hij er niet voor om ieder digitaal medium (zoals een e-mail of sms) in extenso te regelen. Dat houdt immers een te groot risico in om vlug achterhaald te zijn. In plaats daarvan heeft de wetgever functionele definities voor het geschrift (art. 8.1, $1^{\circ} \mathrm{BW}$ ) en de handtekening (art. 8.1, $2^{\circ} \mathrm{BW}$ ) in het wetboek ingeschreven (zie supra). Deze definities zouden voldoende tijdloos moeten zijn om minstens de rest van de 21ste eeuw te doorstaan.

Een andere opening voor het digitale tijdperk is te vinden in art. 8.20 BW. Deze bepaling behoudt het vormvereiste van het meervoudig origineel voor wederkerige contracten. Net zoals onder het oud Burgerlijk Wetboek moeten er bij dat soort contracten evenveel originele exemplaren worden opgemaakt als er partijen zijn met een onderscheiden belang. Boek 8 vult dit principe aan met een specifieke regel voor contracten in elektronische vorm. Luidens het tweede lid van art. 8.20 wordt het vereiste geacht te zijn vervuld voor de contracten in elektronische vorm wanneer het geschrift is opgemaakt overeenkomstig art. $8.1,1^{\circ}$ (zie supra) en het procedé iedere partij de mogelijkheid biedt over een schriftelijk exemplaar te beschikken of toegang ertoe te hebben. In dat verband is ook het vijfde lid vermeldenswaardig, dat een jurisprudentiële uitzondering codificeert op het vormvereiste. ${ }^{67}$ Die uitzondering houdt in dat er geen twee originele exemplaren hoeven te zijn voor contracten afgesloten via briefwisseling. Nieuw is evenwel de uitdrukkelijke toevoeging dat het gaat om brieven verstuurd via zowel de post als elektronisch.

65 B. Cattoir, Nieuw burgerlijk bewijsrecht, Mechelen: Wolters Kluwer 2020, p. 106-107, nr. 187; Samyn 2012, p. 423, nr. 590.

66 Allemeersch, Samoy \& Vandenbussche 2015, p. 900-906.

67 Luik 15 maart 2000, TBBR 2001, 176

\subsection{Het verduidelijken van de regels inzake bewijslast en het expliciteren van de bewijsstandaard}

\subsubsection{Het uitgangspunt van de bewijslast}

Boek 8 besteedt veel aandacht aan het leerstuk van de bewijslast, dat een prominente plaats krijgt in art. 8.4 BW. Het eerste lid herformuleert het algemene uitgangspunt inzake bewijslastverdeling:

'Hij die meent een ander in rechte te kunnen aanspreken, moet de rechtshandelingen of feiten bewijzen die daaraan ten grondslag liggen.'

Deze bepaling wordt in België - net zoals het vroegere art. 1315 oud BW - vaak in één adem genoemd met art. 870 Gerechtelijk Wetboek, luidens dewelke iedere partij het bewijs moet leveren van de feiten die zij aanvoert. In tegenstelling tot de Franse hervorming in 2016, ${ }^{68}$ stapt de nieuwe formulering in het Belgische recht af van het begrip 'uitvoering van een verbintenis'. ${ }^{69}$ Daarmee bevestigt de Belgische wetgever dat deze bepaling een ruimer toepassingsgebied heeft dan enkel verbintenissen, hoewel dat vroeger eigenlijk ook al werd aangenomen. ${ }^{70}$ Art. 8.4 BW komt dicht in de buurt van art. $150 \mathrm{Rv}$ :

'De partij die zich beroept op rechtsgevolgen van door haar gestelde feiten of rechten, draagt de bewijslast van die feiten of rechten.'

Niettemin legt art. $150 \mathrm{Rv}$ nog veel meer de nadruk op de rechtsgevolgen van de feiten waarop een partij die deze feiten stelt, een beroep doet. In Nederland is het dus niet de processuele positie van een partij (eiser of gedaagde) die bepalend is voor de bewijslastverdeling, maar het door iedere partij ingeroepen rechtsgevolg. ${ }^{71}$

Art. 8.4, tweede lid BW omschrijft de situatie waarbij de tegenpartij een bevrijdend verweer opwerpt:

'Hij die beweert bevrijd te zijn, moet de rechtshandelingen of feiten bewijzen die zijn bewering ondersteunen.'

In tegenstelling tot de vroegere wettekst verwijst dit lid niet langer naar de begrippen betaling of tenietgaan van de verbin-

68 Zo verduidelijkt de parlementaire voorbereiding van Boek 8: 'De nieuwe tekst van het Franse Burgerlijk Wetboek blijft zeer trouw aan de oude tekst van art. 1315 van het Burgerlijk Wetboek en bijgevolg nauw verbonden met het verbintenissenrecht' (MvT bij Wetsontwerp van 31 oktober 2018 houdende invoeging van Boek 8 'Bewijs' in het nieuw Burgerlijk Wetboek, Parl. St. 2018-19, nr. 3349/00, p. 13). Art. 1353 van de Franse Code civil luidt als volgt: 'Celui qui réclame l'exécution d'une obligation doit la prouver.'

69 Art. 1315 oud BW luidde als volgt: 'Hij die de uitvoering van een verbintenis vordert moet het bestaan daarvan bewijzen.'

70 Zie o.m. H. De Page, Traité élémentaire de droit civil belge, III, Brussel: Bruylant 1967, p. 731, nr. 726; J. Kirkpatrick, 'Essai sur les règles régissant la charge de la preuve en droit belge', in: X. (red.), Liber amicorum Lucien Simont, Brussel: Bruylant 2002, p. 105, nr. 1.

71 Asser 2021, p. 148. 
tenis. ${ }^{72}$ Met de keuze voor de algemene term bevrijding onderschrijft de wetgever de ruime invulling die de rechtspraak reeds toekende aan deze regel. In het verleden liet men bijvoorbeeld het opwerpen van de verjaring, het verval van verzekeringsdekking of zwarigheden tegen een gedwongen tenuitvoerlegging onder deze bepaling vallen. ${ }^{73}$ In Nederland geldt art. $150 \mathrm{Rv}$ zowel voor de rechtsgevolgen van de door de eiser gestelde feiten als voor de rechtsgevolgen van de door de verweerder gestelde bevrijdende feiten. De verweerder die een zelfstandig of bevrijdend verweer voert,,$^{74}$ beroept zich op rechtsgevolgen van door hem gestelde (bevrijdende) feiten. Een afzonderlijke paragraaf over de bewijslast van de tegenpartij, die vasthangt aan haar procespositie, zou dus geen enkel nut hebben in het Nederlandse recht.

\subsubsection{Medewerking aan de bewijsvoering}

Art. 8.4 BW verankert en veralgemeent in een derde lid de plicht tot medewerking van de partijen aan de bewijsvoering. Het Belgische Hof van Cassatie erkende de verplichting van de partijen tot loyale medewerking als algemeen rechtsbeginsel in het arrest van 25 september 2000 in de context van de overlegging van stukken. ${ }^{75}$ Daarmee stond vast dat de partijen verplicht zijn om mee te werken aan een onderzoeksmaatregel die de rechter heeft bevolen, ongeacht of ze de bewijslast dragen en ook al moeten ze daardoor bewijselementen naar voor brengen die in hun eigen nadeel zijn (bewijsmedewerking sensu stricto). ${ }^{76}$ Een aanzienlijk deel van de Belgische rechtsleer ging ervan uit dat partijen niet alleen een medewerkingsplicht hebben ten opzichte van de rechter, maar tot op zekere hoogte ook een samenwerkingsplicht ten aanzien van elkaar (bewijsmedewerking sensu lato). ${ }^{77}$ Een andere strekking in de doctrine wees een dergelijke veralgemeende verplichting resoluut af. ${ }^{78}$ Boek 8 makt een einde aan deze controverse en bevestigt het veralgemeende en dus ruime toepassingsgebied van de plicht tot medewerking van de partijen aan de bewijsvoering. ${ }^{79}$

72 Art. 1315, tweede lid oud BW luidde als volgt: 'Omgekeerd moet hij die beweert bevrijd te zijn, het bewijs leveren van de betaling of van het feit dat het tenietgaan van zijn verbintenis heeft teweeggebracht.'

73 Allemeersch, Samoy \& Vandenbussche 2015, p. 731-753.

74 Voor rechtspraak: HR 18 oktober 2013, ECLI:NL:HR:2013:979, r.o. 3.3.4; Hof 's-Gravenhage 21 april 2009, ECLI:NL:GHSGR:2009: BI3176, r.o. 8. Voor rechtsleer: Rutgers \& Krans 2014, p. 44.

75 Cass. 25 september 2000, ECLI:BE:CASS:2000:ARR.20000925.6.

76 Allemeersch, Samoy \& Vandenbussche 2015, p. 697, nr. 103.

77 B. Allemeersch, Taakverdeling in het burgerlijk proces, Antwerpen: Intersentia 2007, p. 470, nr. 170; Cattoir 2013, p. 127, nr. 246; D. Mougenot, 'La preuve', in: Rép.not., IV. Les obligations, Brussel: Larcier 2012, p. 119120, nr. 31; W. Vandenbussche, “Je t'aime..., moi non plus”. Over de loyale medewerking aan de bewijsvoering in het buitencontractueel aansprakelijkheidsrecht', in: T. Vansweevelt \& B. Weyts (red.), Actuele ontwikkelingen in het aansprakelijkheidsrecht $\sigma^{\circ}$ verzekeringsrecht, Antwerpen: Intersentia 2015, p. 94, nr. 17.

78 L. Cornelis, Algemene theorie van de verbintenis, Antwerpen: Intersentia 2000, p. 214; Samyn 2012, p. 135.

79 MvT bij Wetsontwerp van 31 oktober 2018 houdende invoeging van Boek 8 'Bewijs' in het nieuw Burgerlijk Wetboek, Parl. St. 2018-19, nr. 3349/001, p. 13.
Met het invoeren van een algemene verplichting tot bewijsmedewerking streeft de Belgische wetgever ernaar om in de loop van de procedure zo veel mogelijk informatie en bewijs boven tafel te krijgen. Die beweegreden speelt ook mee bij het Nederlandse Wetsvoorstel 35498. Het uitgangspunt van dit wetsvoorstel is dat de rechter uiterlijk op het moment van de mondelinge behandeling beschikt over alle nodige informatie betreffende de zaak. ${ }^{80}$ Het Nederlandse voorstel bevat een aantal specifieke voorschriften hieromtrent, met name een bewijsverzamelplicht (art. 21 lid 2 Rv-Ontwerp), het recht van een partij op informatieverschaffing en de plicht daartoe van de wederpartij (art. $194 \mathrm{Rv}$-Ontwerp) en een verbetering van het inzagerecht (art. $196 \mathrm{Rv}$-Ontwerp).

De Belgische verplichting tot bewijsmedewerking is daarentegen heel wat minder concreet. Niettemin blijkt uit een analyse van de rechtspraak dat het gaat om een paraplubegrip dat meerdere facetten omvat. ${ }^{81}$ Zo vloeit er een minimumverwachting uit voort dat een partij bewijselementen voorlegt ter ondersteuning van haar eigen positie, ook al draagt zij niet het bewijsrisico. Zij kan niet vasthouden aan een of andere bewijsrangorde. Een totaal passieve houding, waarbij zij afwacht totdat de aanvoerende partij al haar bewijs heeft geleverd alvorens zelf aan zet te komen, is ongeoorloofd. ${ }^{82}$ Daarnaast gaat het om een verbod op bewijsobstructie, ${ }^{83}$ een verplichting om informatie mee te delen ${ }^{84}$ en zelfs een gehoudenheid om concrete bewijselementen naar voren te brengen, zonder daartoe enig bevel van de rechter te hebben ontvangen. ${ }^{85}$ Dit laatste deelaspect vertoont dus opmerkelijke gelijkenissen met wat de Nederlandse wetgever via de verplichting tot informatieverschaffing aan de tegenpartij in art. $194 \mathrm{Rv}$-Ontwerp wil bereiken. Die plicht heeft eveneens als doelstelling om te voorkomen dat steeds een rechterlijke tussenkomst noodzakelijk is om een partij ertoe te bewegen informatie te delen met haar wederpartij. ${ }^{86}$

Verder zijn er in België uitspraken te vinden over de verplichting tot medewerking aan de bewijsvoering in de preprocessuele fase. ${ }^{87} \mathrm{Er}$ is dus ook enige overeenstemming met de bewijsverzamelplicht, zonder dat deze in België als dusdanig geconcretiseerd wordt. Evenmin doet de verplichting tot bewijsmedewerking de vrees ontstaan dat partijen voorafgaandelijk aan de procesinleiding buitengerechtelijk om de afgifte van bescheiden en schriftelijke getuigenverklaringen zullen

80 Kamerstukken II 2019/20, 35498, nr. 3, p. 1

81 Vandenbussche 2017, p. 334, nr. 384; W. Vandenbussche, 'Omgaan met bewijsnood bij aansprakelijkheid uit onrechtmatige daad', $R W 2018-19$, p. 336.

82 ArbH. Antwerpen 19 januari 2009, Limb.Rechtsl. 2009, 129, m.nt. S. Renette; Arbh. Brussel 19 december 2006, Soc.Kron. 2008, 552.

83 Gent 27 juni 2019, RW 2020-21, 578.

84 Cass. 14 november 2013, ECLI:BE:CASS:2013:ARR.20131114.4.

85 Cass. 7 juni 2019, ECLI:BE:CASS:2019:ARR.20190607.5.

86 R.H. de Bock, 'Het fundament en de pijlers van het Wetsvoorstel vereenvoudiging en modernisering bewijsrecht', RMThemis 2020, afl. 6, p. 249

87 Rb. Brussel 29 januari 2018, For.ass. 2019, 136, m.nt. J.-L. Fagnart, T.Gez., 2020-21, 68, m.nt. M. Verhaegen; Rb. Brussel 2 februari 2015, RGAR 2015, nr. 15207. 
verzoeken. ${ }^{88}$ De Belgische benadering heeft als voordeel dat zij het mogelijk maakt om nieuwe toepassingen te omvatten die zich in de praktijk kunnen voordoen en niet altijd voorzien zijn. Het nadeel ervan is dat de concrete invulling van de verplichting tot bewijsmedewerking niet altijd even duidelijk is, hetgeen tot discussies kan leiden over de precieze grenzen. ${ }^{89}$

\subsubsection{De theorie van het bewijsrisico}

In het vierde lid codificeert art. 8.4 BW de theorie van het bewijsrisico:

'In geval van twijfel wordt hij die de door hem beweerde rechtshandelingen of feiten moet bewijzen, in het ongelijk gesteld, tenzij de wet anders bepaalt.'

Ook het Nederlandse recht is vertrouwd met de theorie van het bewijsrisico. Het bewijsrisico dient in Nederland eveneens als een middel voor de rechter om te bepalen voor rekening van welke partij de omstandigheid moet komen dat een feit onbewezen is gebleven. ${ }^{90}$

\subsubsection{De bevoegdheid van de rechter tot bewijsrisico- omkering}

Het vijfde lid van art. 8.4 BW bevat een opmerkelijke vernieuwing, met name de invoering van een rechterlijke bevoegdheid tot omkering van het bewijsrisico. De memorie van toelichting duidt dit zelf aan als een punt waar het ontwerp een breuk teweegbrengt in vergelijking met het huidige recht. ${ }^{91}$ De wettelijke bewoordingen luiden als volgt:

'De rechter kan, bij een met bijzondere redenen omkleed vonnis, in het licht van uitzonderlijke omstandigheden, bepalen wie de bewijslast draagt wanneer de toepassing van de in de vorige leden opgelegde regels kennelijk onredelijk zou zijn. De rechter kan slechts gebruik maken van deze mogelijkheid wanneer hij alle nuttige onderzoeksmaatregelen heeft bevolen en erover gewaakt heeft dat de partijen meewerken aan de bewijsvoering, zonder op die manier voldoende bewijs te verkrijgen.'

Het introduceren van deze nieuwe techniek is niet onopgemerkt voorbijgegaan. Waar sommige auteurs zich licht positief uitdrukken over de invoering van dit mechanisme, ${ }^{92}$ vrezen andere dat een dergelijke mogelijkheid aan de rechter een te grote beoordelingsbevoegdheid biedt. Dit zou kunnen leiden tot

88 R. Ubels \& T. van Amsterdam, 'Een kritische beschouwing over het Wetsvoorstel ter vereenvoudiging en modernisering van het bewijsrecht', TCR 2019, afl. 1, p. 25.

89 W. Vandenbussche, 'L'obligation de collaborer à l'administration de la preuve: précisions sur la portée d'un principe particulier', $R C J B$ 2021, p. 251.

90 Asser Procesrecht/Asser 3 2017/283.

91 MvT bij Wetsontwerp van 31 oktober 2018 houdende invoeging van Boek 8 'Bewijs' in het nieuw Burgerlijk Wetboek, Parl. St. 2018-19, nr. 3349/001, p. 5.

92 Clijmans 2019, p. 93. een mindere voorspelbaarheid en een mogelijke toename van het aantal rechtsgedingen. ${ }^{93}$

De parlementaire voorbereiding van Boek 8 geeft uitdrukkelijk aan dat dit nieuwe mechanisme zich laat inspireren op art. $150 \mathrm{Rv} .{ }^{94}$ De bewijsrisico-omkering zou evenwel niet berusten op de concepten 'redelijkheid en billijkheid' van het Nederlandse recht. Deze zijn in België niet bekend. Hoewel dat uiteindelijk misschien op hetzelfde neerkomt, hanteert art. 8.4 BW de 'uitzonderlijke omstandigheden' en de 'kennelijk onredelijke toepassing van de basisregels' als inhoudelijke criteria. Voorts vermeldt de memorie van toelichting trouwens dat het gaat om een ultimum remedium of "une soupape de sécurité" of veiligheidsklep. ${ }^{95}$ Op dat punt vindt de Belgische hervorming opnieuw aansluiting bij het Nederlandse recht. De Hoge Raad predikt eveneens terughoudendheid bij het aanwenden van een bewijsrisico-omkering op grond van de redelijkheid en billijkheid. ${ }^{96}$ Hetzelfde geluid weerklinkt in een deel van de Nederlandse rechtsleer. ${ }^{97}$

Verder geeft de parlementaire voorbereiding van Boek 8 ook inzage in een aantal situaties waarbij een bewijsrisico-omkering gerechtvaardigd zou zijn. Dat is het geval wanneer de medewerking aan de bewijsvoering onwerkzaam is geworden omdat de tegenpartij niet meer in staat is om het bewijs dat ze in handen had te leveren, ongeacht of de verdwijning van dat bewijs al dan niet te wijten is aan een intentionele fout van haar kant. Daarnaast zou deze bepaling ook toelaten om een foutieve weigering van een van de partijen om mee te werken aan de bewijsvoering te bestraffen..$^{98}$ Opvallend genoeg stemmen deze potentiële toepassingen overeen met een situatie waarin de Hoge Raad de bewijsrisico-omkering op grond van de redelijkheid en billijkheid heeft aanvaard, met name bij een onredelijke verzwaring door de tegenpartij van de bewijspositie van de aanvoerende partij. ${ }^{99}$ Ten slotte zou de uitzonde-

93 B. Vanlerberghe, 'Hoofdstuk III. De bewijslast', in: T. Vansweevelt \& B. Weyts (red.), Handboek verbintenissenrecht, Antwerpen: Intersentia 2019, p. 1039-1040, nr. 1407.

94 Daarnaast verwijst de MvT naar de vaste rechtspraak van het Oostenrijkse Obergerichtshof als inspiratiebron (MvT bij Wetsontwerp van 31 oktober 2018 houdende invoeging van Boek 8 'Bewijs' in het nieuw Burgerlijk Wetboek, Parl. St. 2018-19, nr. 3349/00, p. 14).

95 MvT bij Wetsontwerp van 31 oktober 2018 houdende invoeging van Boek 8 'Bewijs' in het nieuw Burgerlijk Wetboek, Parl. St. 2018-19, nr. 3349/00, p. 14.

96 HR 9 september 2005, ECLI:NL:HR:2005:AT8238, NJ 2006/99, r.o. 4.3.2; HR 7 mei 2004, ECLI:NL:HR:2004:AO2988, JBPR 2004/48, m.nt. C.J.M. Klaassen, NJ2004/422, m.nt. W.D.H. Asser, r.o. 3.4.

97 I. Giesen, Bewijs en aansprakelijkheid, Den Haag: Boom Juridische uitgevers 2001, p. 98-99; H.W.B. Thoe Schwartzenberg, Civiel bewijsrecht voor de rechtspraktijk, Apeldoorn: Maklu 2013, p. 107; Beenders, in: TEC Burgerlijke rechtsvordering 2021, art. 150, aant. 4; R.P. Wijne, Aansprakelijkheid voor zorggerelateerde schade, Den Haag: Boom Juridische uitgevers 2013, p. 227.

98 MvT bij Wetsontwerp van 31 oktober 2018 houdende invoeging van Boek 8 'Bewijs' in het nieuw Burgerlijk Wetboek, Parl. St. 2018-19, nr. 3349/001, p. 15.

99 HR 20 januari 2006, ECLI:NL:HR:2006:AU4529, NJ 2006/78, r.o. 3.57. Voor lagere rechtspraak, zie Rb. Oost-Brabant 24 december 2014, ECLI:NL:RBOBR:2014:8103, r.o. 3.8. 
ringsregel uit art. 8.4, vijfde lid BW de Belgische rechter ook toelaten om rekening te houden met een aanzienlijk onevenwicht in bewijsgeschiktheid. Dat is het geval wanneer het opstellen, bijhouden of leveren van bewijs buitensporig zwaar of duur is voor een van de partijen. ${ }^{100}$ Die ongelijke bewijsgeschiktheid wordt in zekere zin ook gehanteerd in een aantal uitspraken van de Hoge Raad. Een eerste illustratie is de zaak waarin de rechter had geoordeeld dat een partij een bijzonder vertrouwen mocht stellen in de andere partij als echtgenoot en notarieel jurist. ${ }^{101}$ Hetzelfde geldt voor een arrest waarin de Hoge Raad aanvaardde dat de appelrechter de stelplicht en de bewijslast had omgekeerd met betrekking tot de tussen partijen omstreden schenking. ${ }^{102}$

\subsubsection{De bewijsstandaard}

De term bewijsstandaard klinkt de Nederlandse lezer waarschijnlijk niet zo bekend in de oren. Dat was in België tot en met de hervorming van het bewijsrecht niet anders. Meer zelfs, in tegenstelling tot in andere continentaal-Europese rechtsstelsels (zoals Duitsland, Oostenrijk en Zwitserland), was de belangstelling voor de bewijsstandaard in het Belgische recht gedurende lange tijd uiterst gering. Men beperkte zich meestal tot het beginsel dat de rechter persoonlijk overtuigd diende te zijn van de waarachtigheid van het te bewijzen feit. Dat is de leer van de innerlijke overtuiging. ${ }^{103}$ Ook in Nederland gaat het er uiteindelijk om dat de rechter overtuigd wordt van de waarheid van een feit. ${ }^{104}$

Boek 8 zet een belangrijke stap inzake de juridisering van de bewijswaardering. Het voegt een afdeling toe aan het hoofdstuk met algemene bepalingen die gewijd is aan de bewijsstandaard. Hoewel deze term niet wordt gedefinieerd, duidt het volgens de gangbare opvatting op de intensiteit waarmee een bepaald feit moet worden bewezen. ${ }^{105}$ Het is met andere woorden een mechanisme dat de rechter sturing kan geven bij de beslissing om een bepaald feit al dan niet bewezen te verklaren. ${ }^{106}$ In de Nederlandse rechtsleer duikt hiervoor de term bewijswaarderingsmaatstaf op. ${ }^{107}$ Terwijl het concept van de bewijswaarde betrekking heeft op een afzonderlijk bewijsmiddel (zie supra, par. 3.1.1), houdt de bewijsstandaard verband met de beoordeling van het geheel van bewijselementen die naar boven zijn gebracht.

$100 \mathrm{MvT}$ bij Wetsontwerp van 31 oktober 2018 houdende invoeging van Boek 8 'Bewijs' in het nieuw Burgerlijk Wetboek, Parl. St. 2018-19, nr. 3349/001, p. 15.

101 HR 9 september 2005, ECLI:NL:HR:2005:AT8238, NJ 2006/99, r.o. 4.3.2.

102 HR 31 maart 2017, ECLI:NL:HR:2017:565, NJ 2017/254, m.nt. L.C.A. Verstappen, r.o. 3.4.4.

103 Allemeersch 2007, p. 463.

104 Concl. A-G Drijber onder HR 24 april 2020, ECLI:NL:HR:2020:807, nr. 3.20 .

105 Allemeersch, Samoy \& Vandenbussche 2015, p. 951, nr. 464.

106 Vandenbussche 2018-19, p. 326, nr. 10.

107 R. de Bock, Tussen waarbeid en onzekerbeid. Over het vaststellen van feiten in de civiele procedure, Deventer: Kluwer 2011, p. 279-280; Giesen 2001, p. 103.
Art. 8.5 BW bevestigt de algemene regel, de normale bewijsstandaard, zoals trouwens ook aangenomen werd in de cassatierechtspraak: ${ }^{108}$

'Behalve in de gevallen waarin de wet anders bepaalt, moet het bewijs geleverd worden met een redelijke mate van zekerheid.’

De parlementaire voorbereiding verduidelijkt wat het begrip redelijke mate van zekerheid betekent:

'Het gaat dus niet om 100\% zekerheid, maar om een overtuiging die elke redelijke twijfel uitsluit. ${ }^{109}$

Aan de ene kant is geen absolute of wetenschappelijk empirische zekerheid vereist. Aan de andere kant is een loutere waarschijnlijkheid onvoldoende. Het Duitse recht spreekt in dat verband over een voor de praktijk bruikbare mate van zekerheid. Deze moet de bovenhand halen op de twijfel, zonder die twijfel volledig te hoeven uitsluiten. ${ }^{110}$ Luidens art. 8.4, vierde lid BW zijn de beweerde rechtshandelingen of feiten bij twijfel niet bewezen (zie supra, par. 3.4.3). Twijfel houdt een maatstaf in die eveneens betrekking heeft op de intensiteit, zodat ook in art. 8.4 reeds een aanwijzing te vinden is over de normale bewijsstandaard. In het Nederlandse recht is de normale bewijswaarderingsmaatstaf vergelijkbaar met België. Bij de feitenvaststelling komt het erop aan dat de rechter de overtuiging krijgt dat een feit met een redelijke mate van zekerheid waar is. ${ }^{111}$

Art. 8.6 BW bepaalt twee typegevallen waarin de rechter genoegen kan nemen met het aantonen van een lagere bewijsstandaard, met name een waarschijnlijkheid. Het eerste lid codificeert een reeds door de rechtspraak erkende uitzondering op de normale bewijsstandaard, de verlaging van de bewijsstandaard bij negatieve feiten:

'Onverminderd de verplichting tot medewerking van alle partijen aan de bewijsvoering, kan hij die de bewijslast draagt van een negatief feit, genoegen nemen met het aantonen van de waarschijnlijkheid van dat feit.'

De partij die het negatief feit moet bewijzen, wordt met andere woorden niet vrijgesteld van het bewijs. $\mathrm{Zij}$ geniet slechts van een verlaging van de bewijsstandaard en moet geen zeker bewijs leveren. Als praktisch voorbeeld denk ik aan de infor-

108 Cass. 1 april 2004, ECLI:BE:CASS:2004:ARR.20040401.16.

$109 \mathrm{MvT}$ bij Wetsontwerp van 31 oktober 2018 houdende invoeging van Boek 8 'Bewijs' in het nieuw Burgerlijk Wetboek, Parl. St. 2018-19, nr. 3349/001, p. 13.

110 BGH 28 maart 1989, VI ZR 232/88, NJW 1989, 3161; BGH 17 februari 1970, III ZR 139/67, NJW 1970, 946, nr. 2.a.

111 HR 19 juli 2019, ECLI:NL:HR:2019:1278, NJ 2020/391, r.o. 2.9.5; HR 16 februari 2018, ECLI:NL:HR:2018:220, NJ 2018/395, m.nt. E. Verhulp, r.o. 3.4.3. Voor Asser Procesrecht/Asser 3 2017/154; I. Giesen, 'De bewijswaardering in civiele zaken: vage noties of scherpe normen?', $A A 1999$, p. 623. 
matiegerechtigde die moet aantonen dat een professioneel bepaalde informatie niet heeft verstrekt. In dat geval kan de informatiegerechtigde volstaan met het aantonen van een waarschijnlijkheid. ${ }^{112}$

Art. 8.6, tweede lid BW is meer vernieuwend, in die zin dat het een tweede algemene uitzondering invoert op de normale bewijsstandaard. Dat is de verlaging van de bewijsstandaard bij bepaalde positieve feiten:

'Hetzelfde geldt voor positieve feiten waarvan het omwille van de aard zelf van het te bewijzen feit niet mogelijk of niet redelijk is om een zeker bewijs te verlangen.'

De parlementaire voorbereiding verduidelijkt dat daar reeds toepassingen van te vinden waren, namelijk bij het bewijs van diefstal ten opzichte van een verzekeraar. Voor dat specifieke geval oordeelde de rechtspraak in het verleden dat het volstond om de waarschijnlijkheid van de diefstal aan te tonen (dat wil zeggen een oprechte verklaring en afwezigheid van verdachte elementen). ${ }^{113}$

Nieuw in België is dus de uitbreiding van die specifieke oplossing tot een algemene regel, geïnspireerd op het Zwitserse recht. In een ruimer perspectief vermijdt de uitbreiding van de uitzondering voor negatieve feiten naar onmogelijk met zekerheid te bewijzen positieve feiten een ongerechtvaardigde ongelijke behandeling. ${ }^{114}$ De parlementaire voorbereiding geeft geen verdere voorbeelden van dergelijke positieve feiten. Het Nederlandse recht kan daarbij tot inspiratie dienen. Voor bepaalde soorten geschilpunten, zoals de vaststelling van schade, ${ }^{115}$ het geval dat de werkgever de ontbinding van de arbeidsovereenkomst verzoekt ${ }^{116}$ of het bewijs van feiten die zich zeer lang geleden hebben voorgedaan, ${ }^{117}$ wordt immers aanvaard dat de rechter mindere eisen stelt aan de bewijsvoering. ${ }^{118}$

De eerste commentatoren reageren gematigd positief over de nieuwe bevoegdheid van de rechter tot verlaging van de be-

112 Luik 1 juni 2016, TBH 2017, p. 433, m.nt. W. Vandenbussche; Antwerpen 10 september 2015, TRV-RPS 2017, 939.

113 Luik 13 november 2017, $P \Xi^{B} B$ 2018, afl. 3, 131; Bergen 15 juni 2017, JT 2017, afl. 6705, 699, RGAR 2017, afl. 10, nr. 15436; Luik 4 januari 2016, JT 2016, afl. 6648, 336, T.Verz. 2018, afl. 2, p. 217.

114 MvT bij Wetsontwerp van 31 oktober 2018 houdende invoeging van Boek 8 'Bewijs' in het nieuw Burgerlijk Wetboek, Parl. St. 2018-19, nr. $3349 / 001$, p. 17.

115 HR 16 oktober 1998, ECLI:NL:HR:1998:ZC2740, NJ 1999/196, r.o. 3.8 .

116 HR 16 februari 2018, ECLI:NL:HR:2018:182, NJ 2018/394, m.nt. E. Verhulp, r.o. 3.4.3.

117 HR 17 februari 2006, ECLI:NL:PHR:2006:AU6927, NJ 2007/285, r.o. 4.8

118 Asser Procesrecht/Asser $32017 / 257$. wijsstandaard in welomschreven gevallen. ${ }^{119}$ De meeste aandacht gaat naar de vraag hoe een onderscheid te maken tussen een 'redelijke mate van zekerheid' en een 'waarschijnlijkheid'. Als bijkomende leidraad voor de invulling van de term waarschijnlijkheid licht de parlementaire voorbereiding van Boek 8 toe:

'Als men dan toch moet spreken over een zekerheidspercentage, zou dat allicht $75 \%$ zijn. ${ }^{120}$

Sommige auteurs beschouwen die cijfermatige gegevens als verbazingwekkend, ${ }^{121}$ of menen dat een dergelijke benadering de rechtsonzekerheid in de hand werkt. ${ }^{122}$ Ook in Nederland is het uitspreken van waarschijnlijkheidspercentages reeds zwaar bekritiseerd. Bij gebrek aan enige toetssteen voor de feitenrechter om die percentages op te baseren, zouden zij enkel schijnzekerheid en schijnprecisie bieden. ${ }^{123}$

Mijns inziens betekent de vermelding ervan vanzelfsprekend niet dat de wetgever ervan uitging dat alles echt meetbaar of verifieerbaar is. In de eerste plaats gaat de innerlijke overtuiging om een puur aanvoelen van de rechter. Een rechter zal zijn mate van overtuiging in een bepaalde zaak meestal niet of niet exact in een bepaald percentage kunnen uitdrukken. Die percentages zijn daarom slechts op te vatten als een ruwe indicatie van de mate van zekerheid in hoofde van een gemiddeld rechter (75\%). Omgekeerd wijzen ze ook op het risico dat zijn overtuiging niet met de werkelijkheid overeenstemt (25\%). ${ }^{124}$ Niettemin moeten wij ons ten volle bewust zijn van de kunstmatige aard van die cijfers.

\section{Besluit}

De doelstelling van deze bijdrage was om de Nederlandse lezer in te wijden in het nieuwe bewijsrecht, zonder daarbij over te gaan tot een systematische bespreking van iedere wetsbepaling. Zoals hoger toegelicht, opteerde de Belgische wetgever voor een voorzichtige hervorming die nog steeds nauw aansluit bij de napoleontische traditie. Zo getuigen bepaalde keuzes (zoals het behoud van het statuut van de gedingbeslissende eed en het vasthouden aan het gereglementeerde bewijsstelsel) van een conservatieve houding ten aanzien van het bewijsrecht. Waar de keuze voor het gereglementeerde bewijsstelsel

119 Zie bijv. V. Ronneau, 'Objet, charge et degré de preuve: une nouvelle partie de Stratego s'annonce', in: D. Mougenot (red.), La réforme du droit de la preuve, Luik: Anthemis 2019, p. 39; B. Vanlerberghe, 'De verzachting van de regels inzake de bewijslast en de aangepaste bewijsstandaard in geval van bewijsnood: mogelijkheden en grenzen', in: J. Rozie e.a. (red.), Bewijsnood na het vernieuwde bewijsrecht, Antwerpen: Intersentia 2020, p. 56.

120 MvT bij Wetsontwerp van 31 oktober 2018 houdende invoeging van Boek 8 'Bewijs' in het nieuw Burgerlijk Wetboek, Parl. St. 2018-19, nr. 3349/001, p. 17, met verwijzing naar Vandenbussche 2017, p. 621, nr. 724 .

121 F. George \& B. Hubeau, 'La réforme de la preuve', in F. George e.a. (red.), Les grandes évolutions du droit des obligations, Limal: Anthemis 2019, p. 188, nr. 15.

122 Clijmans 2019, p. 96.

123 V. van den Brink, 'Stellen, betwisten, bewijzen - een handleiding', Praktisch Procederen 2008, afl. 4, p. 100.

124 Vandenbussche 2017, p. 618, nr. 721. 
nog verantwoord kan worden door het geloof in een beschermingsformalisme, is het behoud van de wettelijke bepalingen over de gedingbeslissende eed toch opmerkelijk. De Belgische wetgever had dus ontegensprekelijk verder kunnen gaan in de hervormingsgedachte.

De grootste vernieuwing, de bevoegdheid van de rechter tot omkering van het bewijsrisico in uitzonderlijke omstandigheden in art. 8.4, vijfde lid BW, bestaat in Nederland al sinds 1988. De impact is wel beperkt gebleven. De vraag is hoe deze figuur in België zal evolueren. Door de gelijktijdige invoering van verlaging van de bewijsstandaard op basis van art. 8.6 BW krijgen de Belgische feitenrechters in ieder geval twee nieuwe mogelijkheden om aan de bewijsproblemen van partijen tegemoet te komen. Daarnaast kunnen zij ook nog steeds gebruik maken van de combinatie feitelijk vermoeden-tegenbewijs, net zoals van de theorie van het verlies van een kans bij onzekere causaliteit. Hoewel er enige overlap bestaat tussen de voorgaande technieken en de proportionele aansprakelijkheid de omkeringsregel en res ipsa loquitur, is het Belgische recht niet vertrouwd met deze remediëringsmechanismen. Het is dan ook niet uitgesloten dat de bewijsrisico-omkering een grotere rol van betekenis zal spelen.

Een van de meest boeiende aspecten is de wettelijke verankering van de verplichting tot medewerking aan de bewijsvoering, waarvan de onderliggende gedachte aansluiting vindt bij het Nederlandse Wetsvoorstel 35498. Waar het Belgische recht gekozen heeft voor een holistische aanpak, stelt de Nederlandse wetgever heel specifieke verplichtingen voorop. De toekomst zal moeten uitwijzen welke benadering de voorkeur verdient. 